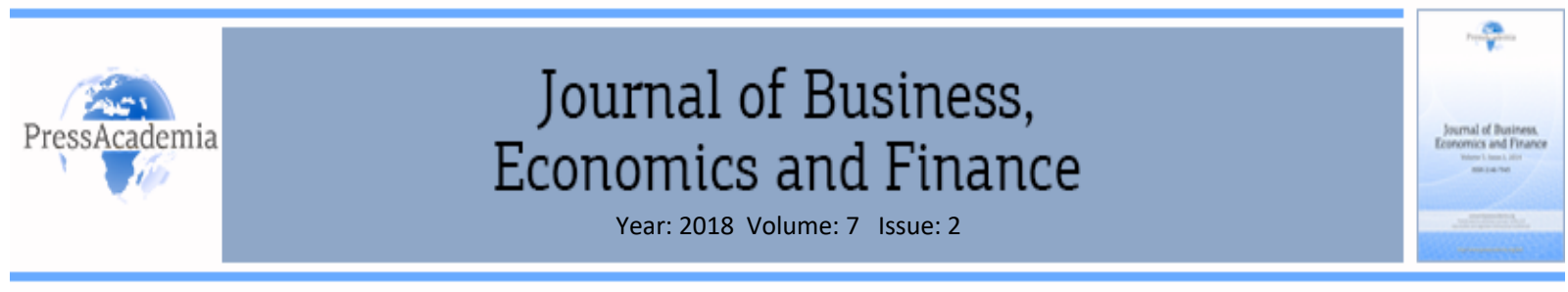

\title{
ANALYZING ASSET OF BUBBLES IN THE HOUSING MARKET WITH RIGHT-TAILED UNIT ROOT TESTS: THE CASE OF TURKEY
}

\author{
DOI: 10.17261/Pressacademia.2018.836 \\ JBEF- V.7-ISS.2-2018(1)-p.139-147 \\ Aslı Afsar ${ }^{1}$, Emrah Dogan² \\ ${ }^{1}$ Anadolu University, Eskisehir Vocational School, Eskisehir, Turkey. \\ aafsar@anadolu.edu.tr, ORCID: 0000-0001-7031-1419 \\ ${ }^{2}$ Anadolu University, Institute of Social Sciences, Department of Economics, Eskisehir, Turkey. \\ emrah.dogan@anadolu.edu.tr, ORCID: 0000-0001-9870-5719
}

To cite this document

Afsar, A., Dogan, E. (2018). Analyzing asset of bubbles in the housing market with right-tailed unit root tests: the case of Turkey. Journal of Business, Economics and Finance (JBEF), V.7(2), p.139-147.

Permemant link to this document: http://doi.org/10.17261/Pressacademia.2018.836

Copyright: Published by PressAcademia and limited licenced re-use rights only.

\section{ABSTRACT}

Purpose- Housing markets are linked to macroeconomic and financial stability. The creation of different financial instruments on residence, the presentation of residence as an assurance, the impact of residence prices on saving and consumption through the wealth effect are some of the housing market and general economic interactions. Developments in the residential sector must be carefully monitored for financial stability. The residential sector has usually played an important role in the global economy and financial sector bubbles. It has been observed that the wealth effect created by the housing bubble surpasses the effect of the stock bubble and that the housing bubble explosion causes more economic devastation compared to the other assets bubbles. While housing markets are increasingly buried in financial markets, the connections between them have strengthened. Such a situation can cause financial crises as a way of extinguishment of a housing bubble. In the case of housing bubbles, bank balance sheets are generally more affected by real estate and it is more likely that the decline in real estate prices are transmitted to the other sectors of the economy with the credit channel. When the housing price bubble burst, the collapse in the financial system is also reflected in the real sector. In this study, with reference to the real housing price index and the real rent price index, it has been investigated whether there is the housing bubble in Turkey.

Methodology- Sup ADF and Generalized SADF (GSADF) tests were used to determine the asset of bubbles and to determine when the housing bubbles had occured. The data set obtained in the study extends from January 2010 to November 2017.

Findings- The results reveal empirical evidence on the absence of speculative bubbles in the Turkish housing market.

Conclusion- There is no data with reference to housing price to say that there is the housing bubble in Turkey during the period under study. Turkey blocked the creation of the housing bubble in the period under review with corrections through its internal dynamics.
\end{abstract}

Key Words: The housing bubble, Turkey, SADF, GSADF

JEL Classification: C20, R31

\section{INTRODUCTION}

Bubbles are typically associated with increases in asset prices and then with a collapse. If the price exceeds the basic value of the asset, the bubbles emerge. This situation may appear if investors hold assets as they believe they can sell for a higher price than other investors even though the price of the asset exceeds its basic value. (Malkiel, 2010: 13). Speculative bubbles are a period when investors are manipulated to an investment irrationally, because the rising prices, at least at some consciousness levels, urge to expect more price increases. A feedback develops; as assets become more and more attractive for people, more and more price increases are made. When people no longer expect the price to increase, the bubble ends up, and the demand falls and the market crashes. (Shiller, 2003: 97). 
One of the earliest known examples of the asset price bubbles is the tulip bubble which started in the Netherlands in 1634 and exploded in February 1637. The most well known examples are real estate bubbles. There are the US land bubble in the 1920s, the Japanese land bubble and the Swedish real estate bubble in the 1990s, the China real estate bubble in the 2000s and the US 2007 housing bubble, which caused a global crisis. When the housing price bubble burst in 2007, the real sector was affected from the collapse in the financial system and caused many countries in the world to go through the recession process.

Real estate, especially the housing market, is an integral part of an economy and is closely related to financial markets. Economic peaks and collapses are closely linked to fluctuations in real estate prices. (Quigley, 2002: 14). Since the 1980s, the real estate sector has played an important role in the global economy and financial sector bubbles. Housing markets are linked to macroeconomic and financial stability, and there are several reasons for that. First of all, the size of the markets is important. The housing loan constitutes a large part of the household credits and usually constitutes a large part of the activities of the financial sector. Secondly, leverage is important. The leverage limits of households through housing loans are higher than the other asset classes. Moreover, real estate is secured not only for households and construction companies, but also for companies in other sectors. (Cerutti, Dagher, Ariccia, 2017: 7). Higher housing prices increase housing demand for households with limited borrowing and cause financial institutions to open credit. That makes the housing market prone to significant price fluctuations. With the effect of initial price increase, feedback investors can continue to buy and sell homes and cause the price increases to continue. (Brunnermeier, Julliard, 2008: 155) As a result, the prices may rise in the short term with the speculations encouraged because of higher earnings than expected. The cyclicality of housing prices may lead to the significant differences in the assurance position of the household on the market cycle. It was observed that the amount of secured loan was closely related to this loan position and that the spread of mortgage rates over risk-free prices varied according to the loan position of each household. (Xiao, Devaney, 2016: 4274).

Because the price of a home depends on its future core values, it is likely that investors undervalue or overestimate the base price in an environment with imperfect (deficient) information. In particular, investors who are overly optimistic about the expected growth can keep the price above the conversion cost. In effective financial markets, deviations from the base price are defrayed by sophisticated investors selling homes until the price returns to its base value. Optimistic investors remain on the market as long as prices are on the rise and financing is available. Long construction time lag prevents rapid provision reaction, so prices continue to rise for a long time and a price bubble develops. Finally, as prices move away from their core values, more and more investors start to sell and the price inflation slows down. When this process gains speed, prices drop suddenly. Such bubbles can logically arise because the nominal asset prices are misdirected from the bases and the short-term incentives of economic operators differ from the long-term benefits. (Zhao et al., 2017:154).

The impact of wealth on housing refers to the expenditures of the households trying to improve their consumption throughout the life cycle and more borrowing as long as the value of the housing assets increases. It is claimed that the valuation of housing prices can redistribute the wealth but not increase it in total and the effect of wealth on consumption and investment is uncertain. There will be a positive asset impact on owners who have a permanent increase in housing prices and tenants. (Aoki, Proudman, and Vlieghe, 2004: 419; Goodhart and Hofmann, 2008: 190). The effects of bubbles formed in different assets on economy are not the same. Investigations have shown that the wealth effect created by the housing bubble surpasses that of the stock bubble. According to some researches, it has also been seen that the burst of stock bubbles caused less damage in the economy compared to the burst of housing bubbles. (Kansu, 2011: 38) One of the reasons for this is that the individual consumption decisions are more sensitive to changes in housing prices than changes in stock prices. This is related to the fact that real estate constitutes the large share of household assets and this is related to establish connection between the banking system with the guarantee of real estate collateral for large share of bank loans. Another reason is the constraint of the effect of the collapse of bank balance sheets in the countries where the purchase of housing is financed with borrowing. Low interest rates make a significant contribution to the housing bubbles and the expansion of the mortgage market. (Machaj, 2016: 392)

The latest crisis in the US shows that the negative impact of the housing bubble burst could be much more destructive due to the fact that the loads related to the residential sector expand mortgage-based securitization into other institutions and investors in the financial system rather than just the usual connection between the bank and the borrowing household (Kansu, 2011: 40).

In the case of housing bubbles, bank balance sheet is generally more affected by real estate and it is more likely that the decline in real estate prices will be transmitted through credit to other sectors of the economy. In part of the literature, it is pointed out that the decline in real estate prices may reduce real investments, as real estate assets are often used as assurance by firms. Moreover, volatility in real estate prices directly affects the construction sector. Finally, the housing excess supply which is a frequent by-product of real estate bubbles is abuse of a resource much more laborious than the 
oversupplying of companies which are a by-product of equity bubbles and can positively contribute to GDP growth. (Scherbina, Schlusche, 2012: 466).

International comparisons lead us to various findings and references. Firstly while housing markets are increasingly buried in financial markets, the connections between them have strengthened. Such a situation can cause financial crises as a way of extinguishment of a housing bubble. Secondly, policy mistakes and mismanagement by the government expedite the collapse of asset bubbles. Thirdly, and most importantly, overly optimistic market confidence is reflected in excessive increases in housing prices and in the prices of related financial products (such as loans, asset-based securities and related financial sector services). As the anticipations of market operators converge more closely on economic foundations, radically changing views lead to very pessimistic price expectations and cause price bubbles to burst and eventually lead to long-term economic recession. Psychological factors play an important role in the economy and unreasonable enthusiasm can cause serious price discordances in housing and financial markets. (Zhao et al., 2017: 156).

In an academic study on the data related to the housing prices, the loans and the mortgage debt in 40 countries from 2000 to 2009 , it has been determined that 87 percent of the countries with a housing bubble burst experienced a financial crisis or a sharp decline in GDP growth. (Both the housing bubble burst and a credit market burst in 91\%) (Crowe et al., 2013: 304).

In this study, the aim is to detect the asset of the bubbles in the housing market by using real housing price index and the real rent price index in Turkey. For this purpose, the monthly data between January 2010 and November 2017 were used and the data were obtained from the CBRT EDDS database. It is aimed to determine whether housing bubbles are present or not with reference to the real housing price index and the real rent price index. The most important feature that distinguishes our study from other studies is that it determines the asset of bubbles using all country data, its dynamic structure makes it possible to predict bubbles in advance unlike indirect methods of the tests SADF and GSADF which are used and to determine when they have occurred in the case of formation of the housing bubble and it achieves more accurate results than standard econometric tests. Besides, in a literature search some studies concerning the bubbles in the housing market in Turkey have been seen and it has been observed that real housing price index and rent price index are not considered together in these studies. Moreover, the housing bubble was intensionally argued in Turkey in 2017. The data set will provide an empirical contribution to this discussion using the dates January 2010 and November 2017. When evaluated in this framework, it is thought that the study will provide important benefits in terms of scope as well as methodology in the literature.

\section{LITERATURE REVIEW}

Many theoretical and empirical studies have been carried out on the housing bubbles in literature. Some of these studies are shown in Table 1.

Table 1: Studies on Housing Bubbles

\begin{tabular}{|c|c|c|l|}
\hline Study & Country/Term & Method & \multicolumn{1}{c|}{ Results } \\
\hline $\begin{array}{c}\text { Ardila et al. } \\
\text { (2013) }\end{array}$ & Switzerland & LPPL Bubble Model & $\begin{array}{l}\text { It was concluded that in 11 critical regions, the } \\
\text { housing bubbles were about to explode, and in 7 } \\
\text { regions the housing bubble bursts. }\end{array}$ \\
\hline Basco (2014) & USA/ 1983-2007 & Fixed Effect OLS & $\begin{array}{l}\text { It is pointed out that with the globalization, } \\
\text { housing prices have increased and the tendency of } \\
\text { appearance of housing bubbles has increased. }\end{array}$ \\
\hline $\begin{array}{c}\text { Zeren and } \\
\text { Ergüzel(2015) }\end{array}$ & $\begin{array}{c}\text { Turkey/2010:01- } \\
2014: 06\end{array}$ & SADF ve GSADF & $\begin{array}{l}\text { There is no housing bubble in Turkey Housing } \\
\text { Market and while the increases seen in the } \\
\text { housing market are experienced in the short term, } \\
\text { it is not permanent in the long term. }\end{array}$ \\
\hline $\begin{array}{c}\text { Caspi(2016) } \\
\text { Engsted et al. } \\
\text { (2016) }\end{array}$ & $\begin{array}{c}\text { Israel/2008q1- } \\
\text { The countries of } \\
\text { OECD/1970-2013 }\end{array}$ & $\begin{array}{c}\text { Right-tailed Unit Root } \\
\text { test and Co-Explosive } \\
\text { VAR }\end{array}$ & $\begin{array}{l}\text { In many housing markets, it has been found that } \\
\text { there is a housing bubble. }\end{array}$ \\
\hline
\end{tabular}




\begin{tabular}{|c|c|c|c|}
\hline $\begin{array}{l}\text { Martori et al. } \\
\quad \text { (2016) }\end{array}$ & Spain/2001-2011 & $\begin{array}{l}\text { Exploratory Spatial Data } \\
\text { Analysis (ESDA) }\end{array}$ & $\begin{array}{l}\text { In the housing bubble of the period in question, } \\
\text { the spatial autocorrelation is growing, and this } \\
\text { growth is greater in urban areas such as Madrid, } \\
\text { Barcelona and Zaragoza than in the past. }\end{array}$ \\
\hline $\begin{array}{l}\text { Solak and } \\
\text { Kabadayı (2016) }\end{array}$ & Turkey & $\begin{array}{c}\text { ARDL } \\
\text { Approach/1964/2014 }\end{array}$ & $\begin{array}{l}\text { It has been emphasized that there is a positive } \\
\text { relationship between housing demand and } \\
\text { housing prices and these findings in the future can } \\
\text { feed a housing bubble in Turkey. }\end{array}$ \\
\hline $\begin{array}{c}\text { Xiao and } \\
\text { Devaney (2016) }\end{array}$ & England/1983-2012 & $\begin{array}{l}\text { Markov Regime Switching } \\
\text { Model }\end{array}$ & $\begin{array}{l}\text { The magnitude of the credit is a big influence on } \\
\text { the housing prices in Great London, and also this } \\
\text { effect has a positive feedback effect due to past } \\
\text { price movements in regions close to Great } \\
\text { London. }\end{array}$ \\
\hline $\begin{array}{l}\text { Çoşkun et al. } \\
\text { (2017) }\end{array}$ & $\begin{array}{l}\text { Turkey/2010:01- } \\
\text { 2014:M12 and } \\
\text { 2007:06-2014:12 } \\
\end{array}$ & $\begin{array}{c}\text { OLS/FMOLS/DOLS, } \\
\text { Kalman filter and ARIMA } \\
\text { models } \\
\end{array}$ & $\begin{array}{l}\text { It has been pointed out that prices were } \\
\text { overvalued in the Turkish housing market, but } \\
\text { there was no bubble in the housing market. }\end{array}$ \\
\hline $\begin{array}{l}\text { Çoşkun and } \\
\text { Jadevicius } \\
\text { (2017) }\end{array}$ & $\begin{array}{l}\text { Turkey/2010:01- } \\
\text { 2014:12 }\end{array}$ & $\begin{array}{l}\text { Right-Tailed ADF Unit } \\
\text { Root Analysis }\end{array}$ & $\begin{array}{l}\text { It was concluded that there is no housing bubble } \\
\text { in the housing market in Turkey. }\end{array}$ \\
\hline Shi (2017) & USA/1978-2015 & VAR & $\begin{array}{l}\text { It was determined that there has been a housing } \\
\text { bubble that began in the mid-2000s in the US } \\
\text { housing market; on regional level there were two } \\
\text { housing bubbles from the end of the } 1980 \text { s and } \\
\text { from the beginning of the } 2000 \text { s to the middle of } \\
\text { the } 2000 \text { s. }\end{array}$ \\
\hline $\begin{array}{l}\text { Vogiazas and } \\
\text { Alexiou(2017) }\end{array}$ & $\begin{array}{c}7 \text { OECD } \\
\text { Country/2002-2015 }\end{array}$ & GMM & $\begin{array}{l}\text { GDP, the credit growth, long-term bond return, } \\
\text { and real effective exchange rate are determinants } \\
\text { of housing prices and also credit-based economies } \\
\text { are influential in the spread of housing bubble. }\end{array}$ \\
\hline
\end{tabular}

From these studies Ardila et al (2013) identified the asset of bubbles in the Swiss housing market and the risk of occurrence, between the year of 2005 and 2013, the development of data of the housing prices in all Swiss regions have been analyzed through the log periodic power law (LPPL) bubble model. In the study, it has been found that housing bubbles were about to explode in 11 critical areas and the housing bubbles burst in 7 areas.

Basco (2014) analyzed the relationship between globalization and the evolution of rational bubbles in the 138 US Metropolitan areas with the data including the period from 1983 to 2007. In the survey carried out with the help of the fixed effect OLS model assumption, it has been found that the bubble will not be formed in a financially developed and autarchic country whereas as globalization increases, the sighting prevalance of bubbles in financially developed countries increases. In the study, it is also pointed out that with globalization, housing prices have also increased and the tendency of appearance of housing bubbles has increased.

Engsted et al.(2016) analysed the housing bubbles with the help of Phillips et al.'s right-tailed unit root analysis and the model of co-explosive VAR of Engsted and Nielsen in the housing market of 18 OECD countries from 1970 to 2013 . The results of the study point to the asset of a housing bubble in many housing markets.

Xiao and Devaney (2016) studied the differences in price- credit relationship with the three-month using the Markov Regime Switching Model data between the years of 1983 and 2012 for 12 regions in the UK. According to the results of the study, it has been emphasized that the magnitude of the credit is a big influence on the housing prices in London, and also this influence has a positive feedback effect due to past price movements in the regions close to Great London.

Martori et al. (2016) made the spatial structure analysis of overgrowth in construction sector with the method of Explanatory Spatial Data Analysis (ESDA) in 6 large metropolitan regions in Spain between in 2001 and 2011. As a result of the study it was concluded that the spatial autocorrelation growed in the housing bubble of the period in question, and this growth was greater in urban areas such as Madrid, Barcelona and Zaragoza than in the past. 
Caspi (2016) investigated whether there was a housing bubble at the regional and national level by right-tailed ADF and Generalized SADF Unit root analysis in Israel housing market in the period between 2008 and 2013. Empirical results indicate the asset of a housing bubble in Israel.

Shi (2017) investigated the asset of housing bubbles in the US national housing market and in 21 regional housing markets between 1978 and 2015 through the model of VAR by considering macroeconomic conditions (interest rate, per capita income, employment, population increase etc.) Findings from the study revealed that there was a housing bubble that began in the mid-2000s in the USA. At the regional level, on the other hand, it was found by the end of the 1980s and from the beginning to the middle of the 2000s that two housing bubbles were formed.

Vogiazas and Alexiou (2017) investigated the relationship between housing prices and the business cycle in 7 OECD countries during the period of 2002-2015 through the model of GMM (Generalized Moments Method). The results obtained show that GDP, the credit growth, long-term bond return, and real effective exchange rate are determinants of housing prices and also credit-based economies are influential in the spread of housing bubble.

On the other hand, the findings of a study where Solak and Kabadayı examined demand for housing in Turkey for the period 1964-2014 with the ARDL Bound Testing Approach revealed a positive relationship between the housing prices and the housing demand. It is emphasised that in the future the relation found in the study might feed a housing bubble in Turkey.

Zeren and Ergüzel (2015) analysed whether housing bubbles existed in Istanbul, Izmir and Ankara, which are the important parts of the Turkish housing market, with SADF and Generalized ADF (GSADF) Unit root analysis between January 2010 and June 2014. According to the results obtained by the researchers, there is no housing bubble in Housing Market in Turkey and the increases observed in the housing market are experienced in the short term, but not permanent in the long term.

Similarly, in an analysis performed with Right-Tailed ADF Unit root analysis in the period between January 2010 and December 2014 in Istanbul, Izmir and Ankara, Çoşkun and Jadevicius (2017) concluded that there was no housing bubble in Turkey Housing Market.

Finally, in order to determine the determinants of housing market in Turkey and the risk of bubble in the housing market, Coşkun et al (2017) used the sub-terms of 2010:01- 2014:12 and 2007:06-2014:12 through OLS/FMOLS/DOLS, Kalman filter and ARIMA models and they indicated that prices in the Turkish housing market were overvalued but that there was no bubble in the housing market.

\section{DATA SET AND METHOD}

In this study, it was aimed to determine the asset of the bubbles in the housing market in Turkey by using real housing price index and the real rental price index. For this purpose, the monthly data between January 2010 and November 2017 were used and the data were obtained from CBRT EDDS database in this study.

In the study, it was examined whether there are bubbles in the housing market by using the method ADF (SADF) of Phillips et al. (2011) and the generalized Dickey Fuller (GSADF) test of Phillips (2015). Because of their good performance in determining the speculative bubbles and when they occur, these methods are recursive and right-tailed unit root tests which have been frequently used in recent times.

The supremum ADF (SADF) test which is one of the most commonly used right-tailed unit root tests performed by Phillips et al. (2011), a standard extended Dickey-Fuller (ADF) test, was developed to determine speculative bubbles and when they occurred and as Homm and Breitung (2012) stated, this test shows great performance as well as other tests using similar procedures. SADF is essentially based on repeated assumption of the standard ADF test. The SADF test is obtained as the lower value corresponding to the ADF statistical sequence and it is determined by estimating the equality given in number 1 equation with minimum squares. (Philips et al. ,2015).

$x_{t}=\mu_{x}+\delta x_{t-1}+\sum_{j=1}^{j} \emptyset_{j} \Delta x_{t-j}+\varepsilon_{x, t}, \varepsilon_{x, t} \sim N I D\left(0, \sigma_{x}^{2}\right)$

For several given values of $J$ in Eq. $1, N D$ shows independent and normal distribution, and $H_{0}: \delta=1$ zero hypothesis and $\mathrm{H}_{01}: \delta>1$ alternative hypothesis are formed in SADF right-tailed unit root test. At each passing one observation is increased in recursive regressions in sample data and as a result it can be estimated recursively using sub-sets.

Sup $_{r \in[r 0,1]} A F_{r} \rightarrow \sup _{r \in[r 0,1]} \frac{\int_{0}^{r} \widetilde{W} d W}{\left(\int_{0}^{r} \widetilde{W}^{2}\right)^{1 / 2}}$ 
Equation number 2 shows the $W$ standard Brownian motion and $\tilde{W}(r)=W(r)-1 / r \int_{0}^{r 1} W$ the minimized Brownian motion. (Philips et al., 2011: 206-207) On the other hand, in case more than one bubble occurs in the literature, Phillips et. al (2015), who considered the criticisms of statistical power reduction of the SADF test, developed the generalized GSADF unit root test to cover the shortcomings of the SADF test. Even though the GSADF test has similiar characteristics with SADF, it differs from SADF as it uses recursive flexible estimations of the regression obtained from the standard ADF test while the test is calculated and takes into account long-running, nonlinear structures and structural breaks. In this regard, GSADF performs more effectively compared to SADF and standard ADF unit root test since it provides more consistent and accurate results in the case of existence of more than one bubble (Phillips et al.,2015). Even though The GSADF test depends on the recursive functioning of the ADF test in sub-samples similar to SADF, it is conceived as the largest ADF test being much wider compared to the SADF test.

Firstly, recursive regression equation number 3 is estimated in order to calculate the GSADF test statistic. Here, the k delay length is included in the equalization to represent the start and end points of the sub-sample, so that $r 1$ and $r 2$ recurcive regression estimations can be respectively performed. (Çağlı and Mandacı,2017:66).

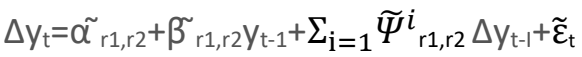

The GSADF test equation number 3 is repeatedly estimated using sub-sets as future-dated for multiple sub-samples and unlike the SADF test, the sub-samples whose start points change dynamically and differentiate from the zero point at $r 1$ are formed instead of the ending points $r 2$ of the sub-samples. (Çağlı and Mandacı,2017:66). Thus the GADF test is calculated by means of the formula given in equation number 4. (Philips, Shi and Yu, 2015: 1049).

$\operatorname{GSADF}\left(\mathrm{r}_{0}\right)=\sup _{\mathrm{r} 2} \in_{\mathrm{r} 1 \in[0, \mathrm{r} 2-\mathrm{r} 1]}\left[\mathrm{r}_{0,1}\right]\left\{\mathrm{ADF}^{\mathrm{r} 2} \mathrm{r}\right\}$

\section{FINDINGS}

In the study, it was aimed to determine whether the housing bubbles exist or not based on real housing price index and real rent price index. For this purpose, in SADF and GSADF tests which are used to determine the asset of bubbles and to determine when the bubbles are formed, Monte Carlo simulation with 1000 replications for each observation was used. The estimation results obtained are given in Table 2 and Table 3. The graphs for the SADF and GSADF tests are shown in Figure 1 and Figure 2.

Table 2: SADF and GSADF Test Results for the Real House Price Index

\begin{tabular}{|c|c|c|c|}
\hline & \multicolumn{3}{|c|}{ Test Statistic } \\
\hline Parameter & \multicolumn{2}{|l|}{ SADF } & GSADF \\
\hline $\begin{array}{l}\text { Real Housing } \\
\text { Price Index }\end{array}$ & \multicolumn{2}{|l|}{$\begin{array}{l}-0.696 \\
(0.49)\end{array}$} & $\begin{array}{l}0.327 \\
(0.35)\end{array}$ \\
\hline \multirow[t]{3}{*}{\begin{tabular}{ll|} 
Real Rent Price \\
Index
\end{tabular}} & $\begin{array}{l}-1.40 \\
(0.85) \\
\end{array}$ & & $\begin{array}{l}-0.218 \\
(0.75) \\
\end{array}$ \\
\hline & \multicolumn{3}{|c|}{ Critical Value } \\
\hline & $\% 1$ & $\% 5$ & $\% 10$ \\
\hline SADF & 0.879 & 0.473 & 0.186 \\
\hline GSADF & 1.571 & 1.113 & 0.887 \\
\hline
\end{tabular}

Note: () refers to the probe values of the variables

The SADF and GSADF test statistics given in Table 2 are statistically insignificant for the real house price index. In other words, this result shows empirical evidence that speculative bubbles do not occur in housing prices. In the light of the this result, Turkey blocked the creation of the housing bubble with adjustments through its internal dynamics and lack of macroeconomic spillover effect from Turkish mortgage markets. The SADF and GSADF graphs given in Figure 1 also indicate the housing price bubbles exist in the middle of 2015 and in the first months of 2017. This finding indicate that if the house prices continue to rise at same rate, there may be a risk of bubbles in housing market in Turkey. 


\section{Figure 1: Graphs of Test Results of Real Housing Price Index in Turkey (SADF and GSADF)}

SADF test

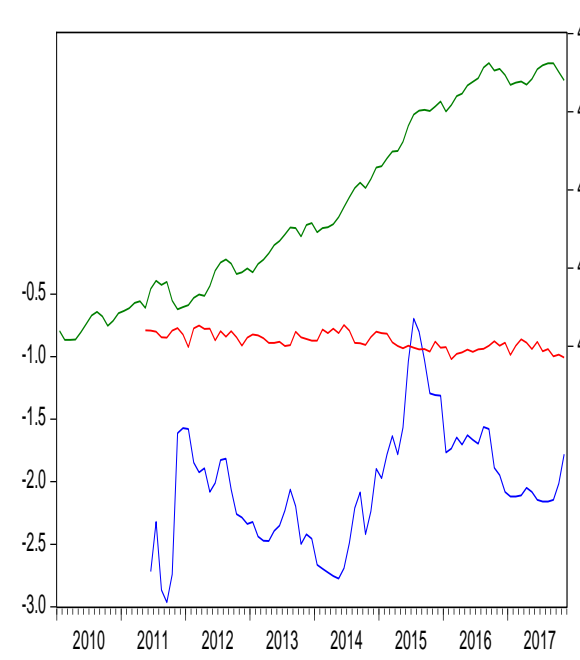

GSADF test

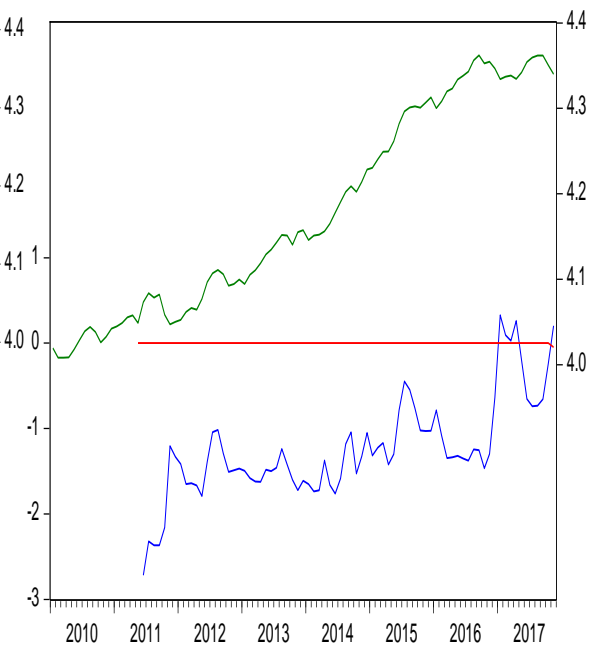

The SADF and GSADF test statistics given in Table 2 for the real rent prices index are also statistically insignificant. This conclusion implies that similar to real house prices index, it can not be concluded that there are bubbles in the speculative housing market. In other words, despite the rise in Turkey's housing rent prices due to the increase in demand for second hand house market and the temporary relocation activities during the demolition and reconstruction of buildings, it is not possible to mention the existence of bubbles in the period under review. The SADF and GSADF graphs given in Figure 2 also show that there is no bubble in the real rent prices index.

Figure 2: Graphs of Test Results of Real Rent Price Index in Turkey (SADF and GSDAF)

SADF tes GSAD Fest
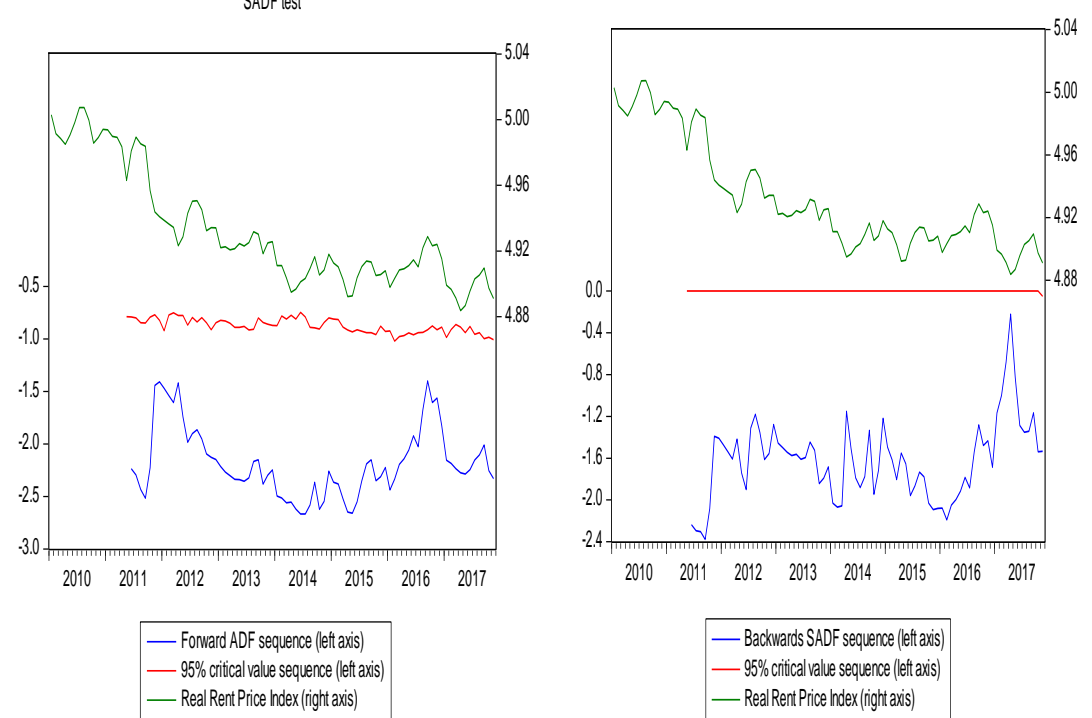

Considering together the results regarding the real housing price index and the real rent prices index in Turkey, even though the results obtained imply that there has been a forward risk of bubble in housing prices recently, it also indicates that housing bubbles were not empirically formed during the period under review. 


\section{CONCLUSION}

Housing market is in serious interaction with the general economy. Creating different financial instruments on housing, presentating housing as assurance, impact of housing prices on saving and consumption through wealth effect are some of these possible interactions. The housing sector generally plays an important role in the global economy and financial sector bubbles. It has been observed that the wealth effect created by the housing bubble is greater than that of the stock bubble and the explosion of the housing bubble causes more damage to the economy than the other asset bubbles. For these reasons, developments in the housing sector should be followed carefully.

In this study, it has been determined whether housing bubbles exist or not based on real housing price index and real rent price index. For this purpose, in SADF and GSADF tests used to determine the asset of bubbles and to determine when the bubbles are formed, the Monte Carlo simulation with 1000 replications for each observation was used. The SADF and GSADF test statistics are statistically insignificant for the real house price index. In other words, this result provides empirical evidence that speculative bubbles do not occur in housing prices in line with Zeren and Ergüzel (2015), Çoşkun et al.(2017) and Çoşkun and Jadevicius (2017). Furthermore, SADF and GSADF graphs indicate that bubbles occur in housing price in the middle of 2015 and in the first months of 2017.

SADF and GSADF test statistics were found statistically insignificant for the real rent prices index. This conclusion implies that in the same way with the real house prices index, there is no bubble in real rent price index in the speculative housing market. Considering together the results regarding the real housing price index and the real rent prices index in Turkey, even though the results obtained imply that there has been a forward risk of bubble in housing prices recently, it also indicates that housing bubbles were not empirically formed during the period under review.

In recent years, the ongoing debate on the question of whether a housing bubble exists in Turkey was also mentioned in the last report of the International Monetary Fund (IMF). In the IMF's Global Monitoring Report in February 2017,it was stated that the value of housing swelled in Turkey but a macroeconomic expansion effect from the housing market was not expected. With population growth, income growth and increase in tendencies to be urbanized, the increase in housing demand all over the world in the last quarter of 1990s led to increase in residential sales prices. This increase turned into a downtick with the global crisis that began in 2008 , but it did not last long. This tendency was experienced with a similar trend in Turkey. In addition, there are country-specific factors which increase significantly the demand for housing in Turkey. $50 \%$ of the population in Turkey is under the age of 30 ,and migration to cities and urban transformation continue. It is estimated that $85 \%$ of the population will be living in cities in 2023 . In addition, infrastructure investments, especially investments in transportation, also support construction and sales of housing. Since new areas can not be created in city centers, prices are swelling with demand, but empirical findings show that we can not generalize it. In the recent period, with increase in exchange rates and interest rates, prices have risen more rapidly in some places and housing stocks of construction companies have increased. It is likely that this factor will also push prices down. This should not be confused with bubbles. As a result, there is no data with reference to housing price to say that there is the housing bubble in Turkey during the period under study. Turkey blocked the creation of the housing bubble in the period under review with corrections through its internal dynamics.

\section{REFERENCES}

Aoki, K., Proudman, J., \& Vlieghe, G. (2004). House prices, consumption, and monetary policy: a financial accelerator approach. Journal of financial intermediation, vol. 13, no. 4, pp. 414-435.

Ardila, D., Cauwels, P., Sanadgol, D., \& Sornette, D. (2013). Is there a real estate bubble in Switzerland?. arXiv preprint arXiv:1303.4514.

Basco, S. (2014). Globalization and financial development: a model of the Dot-Com and the Housing Bubbles. Journal of International Economics, vol. 92, no. 1, pp. 78-94.

Brunnermeier, M. K., \& Julliard, C. (2008). Money illusion and housing frenzies. The Review of Financial Studies, vol. 21, no.1, pp. 135-180.

Caspi, I. (2016). Testing for a housing bubble at the national and regional level: the case of Israel. Empirical Economics, vol. 51, no. 2, pp. 483-516.

Cerutti, E., Dagher, J., \& Dell'Ariccia, G. (2017). Housing finance and real-estate booms: a cross-country perspective. Journal of Housing Economics, vol. 38, pp. 1-13.

Coskun, Y., Jadevicius, A. (2017). Is there a housing bubble in Turkey?. Real Estate Management and Valuation. vol. 25, no. 1, pp. 48-73.

Coskun, Y., Seven, U., Ertugrul, H. M., \& Alp, A. (2017). Housing price dynamics and bubble risk: the case of Turkey. Housing Studies, pp. 137. 
Crowe, C., Dell'Ariccia, G., Igan, D., \& Rabanal, P. (2013). How to deal with real estate booms: lessons from country experiences. Journal of Financial Stability, vol. 9, no. 3, pp.300-319.

Çağlı, E. Ç., \& Mandacı, P. E. (2017). Borsa İstanbul'da rasyonel balon varlığı: sektör endeksleri üzerine bir analiz. Finans Politik \& Ekonomik Yorumlar, vol. 54, no. 629, pp. 63-76.

De Bondt, V., Hunter, W. C., Kaufman, G. G., \& Pomerleano, M. (2003). Asset price bubbles. The Implications for Monetary, Regulatory, and International Policies.

Engsted, T., Pedersen, T. Q., \& Tanggaard, C. (2012). The log-linear return approximation, bubbles, and predictability. Journal of Financial and Quantitative Analysis, vol. 47, no. 3, pp. 643-665.

Engsted, T., Hviid, S. J., \& Pedersen, T. Q. (2016). Explosive bubbles in house prices? Evidence from the OECD countries. Journal of International Financial Markets, Institutions and Money, vol. 40, pp. 14-25.

Goodhart, C., \& Hofmann, B. (2008). House prices, money, credit, and the macroeconomy. Oxford Review of Economic Policy, vol. 24, no. 1, pp. 180-205.

Homm, U. \& Breitung, J. (2012). Testing for speculative bubbles in stock markets: a comparison of alter-native methods. Journal of Financial Econometrics, vol. 10, no.1, pp. 198- 231.

IMF (2017). Global Housing Watch: Quarterly Update, February. http://www.imf.org/external/research/housing/report/pdf/Q1_2017.pdf>, [Last access on:1 March 2018]

Kansu, A. (2011). Konut balonundan finansal krize ABD mortgage krizi. i̇stanbul: Scala Press.

Machaj, M. (2016). Can the Taylor Rule be a good guidance for policy? The case of 2001-2008 real estate bubble. Prague Economic Papers, vol. 2016, no. 4, pp. 381-395.

Malkiel, B. G. (2010). Bubbles in asset prices. CEPS Working Paper, no: 200, pp. 1-21.

Martori, J. C., Madariaga, R., \& Oller, R. (2016). Real estate bubble and urban population density: six Spanish metropolitan areas 20012011. The Annals of Regional Science, vol. 56, no. 2, pp. 369-392.

Quigley, J. M. (2002). Real estate prices and economic cycles. International Real Estate Review, 1999, vol. 2, no. 1, 1 -20.

Phillips, P. C., Shi, S., \& Yu, J. (2015). Testing for multiple bubbles: historical episodes of exuberance and collapse in the S\&P 500. International Economic Review, vol. 56, no. 4, pp. 1043-1078.

Phillips, P. C. B., Wu, Y. \& Yu, J. (2011). Explosive behavior in the 1990s Nasdaq: when did exuberance escalate asset values?. International Economic Review, vol. 52, no. 1, pp. 201-26.

Scherbina, A., \& Schlusche, B. (2012). Asset bubbles: an application to residential real estate. European Financial Management, vol. 18, no. 3, pp. 464-491.

Shi, S. (2017). Speculative bubbles or market fundamentals? An investigation of US regional housing markets. Economic Modelling, vol. 66, pp. 101-111.

Shiller, R. J. (2003). From efficient markets theory to behavioral finance. Journal of economic perspectives, 17(1), pp. 83-104.

Solak, A. O., \& Kabaday, B. (2016). Bounds testing approaches to housing demand in Turkey: is there a real estate bubble?. International Journal of Economics and Financial Issues, vol. 6, no. 3, pp. 1132-1135.

Xiao, Q., \& Devaney, S. (2016). Are mortgage lenders guilty of the housing bubble? A UK perspective. Applied Economics, vol. 48, no. 45, pp. 4271-4290.

Vogiazas, S., \& Alexiou, C. (2017). Determinants of housing prices and bubble detection: evidence from seven advanced economies. Atlantic Economic Journal, vol. 45, no. 1, pp. 119-131.

Zhao, S. X., Zhan, H., Jiang, Y., \& Pan, W. (2017). How big is China's real estate bubble and why hasn't it burst yet?. Land Use Policy, vol. 64, pp. 153-162.

Zeren, F., \& Ergüzel, O. S. (2015). Testing for bubbles in the housıng market: further evidence from Turkey. Financial Studies, vol. 19, no. 1, pp. 40-52. 